\title{
The Colophon: Where moving parts come together
}

\author{
Keywords \\ Citation, Colophon, List/Listing, Relationality, Working-with.
}

This proposal considers the colophon as a conceptual structure for thinking through lists and listing within our creative practice(s). Conventionally, the colophon is a short piece of text that details information about the making of a publication or its intended use. Most often, the colophon specifies the how, where, and when: the typeface and paper stock; the location, date, edition number, and method of printing. It can also foreground the relational aspects of publishing the with who or the why here. Colophons appear at the opening or the closing of a publication, and the information within them can form a kind of ballast to what precedes or succeeds them. That is, the listing of the material, processual, and relational labour that went into the making of publications is called forward in the colophon and acknowledged as structural necessity. Often, we are led to ask, how is this conception of the colophon useful in thinking about the other types of lists and listings that make their way into our collective practices? -Runsheets, Material lists, Contents, Title lists, Indexes, Captions, Legends, Rosters, Glossaries, Registers, Manifests, Chronologies-These modes of listing communicate relevant and important contexts and, in that way, become a conceptual part of creative works themselves. As formats, they are all also citational practices where the materials, processes, information, and relations are shared freely - as any written text would be in a publication's reference list. In their book, The Hundreds (2019), cultural theorists Lauren Berlant and Kathleen Stewart list Adorno and Agamben texts next to "An egg-cooking machine" and "A few pansies stuck in a window box" in the reference section, all alphabetised under the title "Some Things We Thought With"1. This type of list (and the concept of a colophon itself) is not an indiscriminate breaking-down into separate parts but a strategic highlighting of the conditions and abstractions of the artwork. The colophon as a structure in this context exists not only to acknowledge what contributes to a publication but also to trace possible points of departure from convention. As a tactic within creative practice, the colophon is like a conceptual abstraction; it holds all of the constituent parts that make up a project in one place. The '-with' that Berlant and Stewart explore is key to the how, where, and when of relations that the doing of listing brings together. As artists working in the inter-related fields of socially engaged art, object-making, installation, and publication, our list of interests include the moon, the water, the sky; flowers, ceramics, printed matter; ducks, snails, butter. This paper will share our three perspectives on listing as a synchronous tactic with the functioning action of a colophon. Where words and images get to turn, twist, veer, bow, dip, and nod, and the conceptual form of a project takes shape with things. 